\title{
Sixteenth-Century Italian, French, Spanish and English Language Learning Material. A Bibliographical Study
}

\author{
Rocío G. Sumillera \\ Universidad de València
}

\begin{abstract}
This bibliographical study offers a list of the first printed language manuals in Western Europe expressly designed to teach a particular foreign language to speakers of a particular tongue. Hence, the study lists references to sixteenth-century grammars, dictionaries and language handbooks with the possible linguistic combinations of Italian, French, Spanish and English, the first three being the most popular modern languages in sixteenthcentury Western Europe and hence the most representative ones offering an insight into the foreign language learning map of the time. The bibliographical study is preceded by an introduction to the manner in which foreign tongues were taught and learned in the early modern period, and is completed by a selection of references to secondary sources that have been researched on each linguistic combination.
\end{abstract}

KEYWORDS: early modern language manuals, sixteenth-century grammars, sixteenth-century dictionaries

In the Middle Ages in Europe, Latin occupied a position of supremacy over vernaculars as the language of the Church and diplomacy, and the main vehicle for the transmission of culture and knowledge. However, as early as the ninth century dialogue manuals and phrasebooks started to appear in response to the demands of traders and travelers. This was the case of two books for instruction in German to upper-class adult speakers of Romance dialects: the Kasseler Gespräche (ninth century), which taught the Bavarian dialect of Old High German, and the Altdeutsche Gespräche or Pariser Gespräche (eleventh century), which provided instruction in

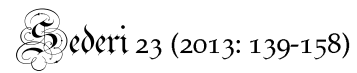

https://doi.org/10.34136/sederi.2013.7 
the colloquial Northwest Franconian (Herbert Penzl 1984). Other short dialogues and glossaries were produced in Greek, Hebrew, Arabic and even Basque to help pilgrims and other Western European travelers and merchants communicate more easily (Brefeld 1994; Kibbee 2000). In addition to commercial transactions, business and trade, knowledge of vernacular tongues also proved of great importance in Christian missions, for even if Latin was the language of the Church, the missionaries would try to learn the vernacular to communicate with the locals, preach, and translate parts of the Bible without the mediation of interpreters (Bischoff 1961:223). From the twelfth, and particularly from the thirteenth century onwards, the supremacy of Latin began to crumble as the vernaculars initiated a process of vindication of their worth to become vehicles of knowledge and culture too.

During the Renaissance, the importance of studying languages multiplied. Even if the stress continued to fall on Latin in the context of classroom language teaching, vernacular languages, particularly French and Italian, got the attention of a wider public interested in learning them. This was partly due to, among other factors, the increase of international travel and cultural and commercial exchanges, as well as an undermining of the dominance of Latin and the rise of the vernacular languages and their literatures. The combination of the invention of the printing press with a growing interest in languages fostered the multiplication of didactic material for instruction in vernacular foreign tongues. Indeed, the appearance of printed handbooks revolutionized the way in which vernacular tongues were taught and learnt, for travelling to foreign countries and private tuition ceased being the only two ways of learning a language. Furthermore, both these methods were "available exclusively to members of the aristocracy or gentry, at least until the latter part of the [sixteenth] century, and, in the case of foreign travel, available only to men" (Lawrence 2005:6). Printed language instruction material thus inaugurates an era of great numbers of autodidacts. At the roots of the study of foreign tongues, there lay a combination of the humanist agenda with a clear utilitarian purpose of a commercial, business-related, educational, or merely leisurederived nature. As a result, fifteenth and particularly sixteenthcentury Europe was flooded with the publication of a wide and varied range of printed materials for the learning of foreign modern tongues: grammars, conversation manuals, books of dialogues, 
compendia of proverbs and letters, dictionaries and glossaries, and volumes that combine in different degrees elements of all the former. Western European students of vernacular languages (among them scholars, diplomats and merchants), translators, and teachers of these languages in the sixteenth century certainly had at their disposal a great variety of didactic materials. The pages below offer an overview on the three main categories of these types of texts ("vocabularies" or conversation books, glossaries and dictionaries, and grammar books); a discussion of some of the authors, writings, and linguistic combinations of these materials will definitely contribute to offering an insight into the complex map of foreign language learning in sixteenth-century Western Europe. ${ }^{1}$

\section{I "Vocabularies" or Conversation Books}

In the Middle Ages, there appears a type of dialogue material known as manières de langage or livres de métiers, which are model conversation books "intended for the use of travelers, merchants, and others desiring a conversational and practical rather than a thorough grammatical knowledge of French" (Simonini 1952:145). The manieres de langage are characterized by the teaching of a language through examples, and consequently, use as their basic pedagogic resource the student's capacity for imitation. The first manière was Livre des mestiers (ca.1349), written in French and Flemish by a schoolteacher of Bruges and intended for tradesmen. Years later, the Maniere de langage qui t'enseignera bien adroit parler et escrire doulz François selon l'usage et la coustume de France (1396) appeared in England, and William Caxton also published conversation books after the manières such as the bilingual Dialogues in French and English (1483), aimed at business and tradesmen.

One of the most important printing nuclei of sixteenth century Europe was Flanders, at the time an important commercial centre and a battlefield where soldiers, merchants and diplomats from various nationalities coexisted. Antwerp became one of the major centres of publication of works for the learning of vernacular

\footnotetext{
${ }^{1}$ This article does not examine teaching materials for the classical languages, which of course does not mean that they did not exist: on the contrary, all throughout Europe Latin, for example, continued to be essential in academic curricula, and it was still in effect a spoken language for many.
} 
languages, and it was in Antwerp that, for instance, Willem Vorsterman published the first phrase book to include Spanish, the Vocabulario para aprender Franches, Espannol y Flaminco (Antwerp, 1520), and a decade later also appeared in Antwerp by the same publisher the anonymous Vocabulaire en troys langues: cest assavoir François, Flameng et Espagnol - the wars in Flanders rendered the vocabularies in these three tongues highly useful. ${ }^{2}$ In 1527 the schoolmaster Noël de Berlaimont (or Barlament) published Vocabulare van nieus geordineert ende wederom gecorrigeert [...]. Vocabulaire de nouneau ordonne et derechief recorrige, a conversation book with a Flemish-French vocabulary intended for merchants and schoolchildren. ${ }^{3}$ The Vocabulare was reprinted over a hundred times in the following one hundred and sixty-two years, on most occasions anonymously under the titles of Vocabulaire, Dictionnaire, Colloquia, Dialogues, or Propos communs, and often adding other languages, thus giving way to numerous polyglot editions. ${ }^{4}$ Other polyglot manuals for traders and artisans with phrases and model dialogues were printed by Bartholomeus van Grave (Gravius), who published, among others, Vocabulaer in vier sprachen Duytsch, François, Latyn ende Spaensch (Louvain, 1551), and Vocabulaire en quatre langues Françoise, Latine, Italienne et Espagnole (Louvain, 1558), a variant of the former that substituted Italienne for Duytsch. Similar works are the Colloquia et Dictionariolum octo linguarum (Antwerp, 1558), and the Diccionario, Coloquios o Diálogos en quatro lenguas, Flamenco, Francés, Español y Italiano con las conjugaciones e instrucciones (Antwerp, 1565), another anonymous publication that appeared in the printing press of Withaye. ${ }^{5}$

\footnotetext{
2 Antwerp effectively constituted the second printing centre for books written by Spanish authors either in Latin or Spanish between 1470 and 1600; Salamanca occupied the first place, and Venice, the third (Fontainas 1965).

${ }^{3}$ The 1536 edition (Antwerp, Willem Vorsterman) is the oldest known copy of the work, whose first edition seems to date from 1527.

${ }^{4}$ The complete inventory of the editions of Berlaimont's Vocabulary can be found in Bourland (1933). See also Stein (1988).

${ }^{5}$ For more on the relevance of Bartholomeus Gravius, see Antonio Roldán Pérez and José Miguel Hernández Terrés (2002).
} 


\subsection{Glossaries and Dictionaries}

Alongside the more popular vocabularies there were polyglot dictionaries for translators, as well as polyglot glossaries appended to Colloquia or grammar manuals. The model for the latter is the Italian scholar Ambrogio da Calepio's Calepino (Reggio Emilia, 1502), a frequently reprinted Latin-Greek and Greek-Latin dictionary that in subsequent years added a number of other languages - the 1605 Basel edition of his Dictionarium undecim linguarum (Latina, Hebraica, Graeca, Gallica, Italica, Germanica, Belgica, Hispanica, Polonica, Ungarica et Anglica) featured eleven different languages. ${ }^{6}$ Furthermore, there existed nomenclatores or nominalia, which grouped words by topics instead of doing so alphabetically. The most famous nomenclatore is probably Hadrianus Junius's Nomenclator omnium rerum propria nomina variis linguis explicata indicans (Augsburg, 1555), which was so successful that it underwent various editions in the Low Countries, France and Germany combining different tongues.

Other early sixteenth century dictionaries for learners of foreign languages are Christoforo de Escobar's Dictionarium trium linguarum (Venice, 1512), in Latin, Italian and Spanish; his Vocabularium ex latino sermone in Siciliensem et hispaniensem denuo traductum (Venice, 1520), and the anonymous Quinque linguarum utilissimus vocabulista Latine Tusche, Gallice, Hyspanice \& Alemanice (Venice, 1513), with later editions in France, Germany, and Italy. Particularly for Italians interested in reading Spanish works we find Alfonso de Ulloa's Glosarios (Venice, 1553), Orazio Toscanella's Dittionario volgare et latino con la lingua Fiamminga, Spanuola et altre lingue (Venice, 1568), with Italian and Latin terms translated mainly into Spanish (although also in Flemish, French, German, Turk and modern Greek), and Christobal de las Casas's Italian-Spanish dictionary Vocabulario de las dos Lenguas Toscana y Castellana, con una introducción para la correcta pronunciación de ambas lenguas (Seville, 1570). De las Casas's is the first proper Italian-Spanish dictionary, and the only one known to have been published in the sixteenth century. It had a considerable impact upon other lexicographers of the time such as Richard Percyvall, John Minsheu and César Oudin. Published later in the century was the Recueil de dictionaires Francoys, Espaignolz et

\footnotetext{
${ }^{6}$ The list of all the editions of the Calepino dictionary and the location of the preserved items can be found in Labarre (1975).
} 
Latins. Recopilacion de Dictionarios Franceses, Españoles y Latinos (Brussels, 1599) by Henricus Hornkens, secretary of archduke Albert, the governor of the Low Countries, who a year before had married Philip II's eldest daughter. This marriage turned proficiency in Castilian into a mark of distinction and good taste at court in Brussels.

The confrontation between Spain and France from the late fifteenth to the end of the seventeenth centuries did not contribute to fostering mutual interest in the respective languages of these nations: as late as 1604 the Parisian printer of Mathieu Guillemot would produce the first Spanish-French dictionary published in France. This was the Diccionario muy copioso de la lengua española y francesa, by Jean Pallet, Henry II's physician. Among the first ItalianFrench bilingual dictionaries, we find the first edition of Francesco Alunno Del Bailo's Le ricchezze della lingua volgare (Venice, 1543), which contains a small French-Italian dictionary by Pannonius, Petit vocabulaire en langue françoise et italienne (Lyon, 1578), and Giovanni Antonio Fenice's Dictionnaire françois et italian (Morges and Paris, 1584).

\subsection{Grammar Books and Other Manuals for the Teaching of Foreign Vernacular Tongues}

Sixteenth-century grammar books of vernacular languages took as models grammars of the classical tongues, hence often explaining the vernaculars against the background or within the framework of Latin grammar. Antonio de Nebrija, author of the first grammar of the Spanish language, Gramática de la lengua castellana (Salamanca, 1492), in his prologue to Queen Isabel of Castile in fact proclaims that one of its objectives was the teaching of Castilian to foreigners as a means of spreading the official language of the nation throughout the dominions of the Spanish Crown. ${ }^{7}$ In the following decades, a number of Spanish grammars for foreign students were published in Louvain and Antwerp: Vtil, y breve institution, para aprender los principios y fundamentos de la lengua Hespañola (Louvain, 1555), in Spanish, French, and Latin; Cristóbal de Villalón's Gramatica

\footnotetext{
${ }^{7}$ Nevertheless, Nebrija's grammar was more academic than practical, and hence, of hardly any use as a learning manual for a foreigner.
} 
castellana (Antwerp, 1558), and the anonymous Gramática de la lengua vulgar de España (Louvain, 1559), written entirely in Spanish. Also in the 1550s, the Flemish language teacher in Antwerp Gabriel Meurier targeted the merchants of the port of Antwerp with his Coniugaisons, regles et instructions mout propres et necessairement requises, pour ceux qui desirent apprendre François, Italien, Espagnol, et Flamen (Antwerp, 1558), followed by Breve instruction contenante la maniere de bien prononcer \& lire le François, Italien, Espagnol, \& Flamen. In a second edition, Meurier limited his book to Spanish and French, entitling it solely in Spanish as Coniugaciones, Arte y Reglas muy propias y necessarias para los que quisieren deprender Español y Frances (Antwerp, 1568). Additionally, Meurier wrote the Vocabulaire François-Flameng (Antwerp, 1557), the Traité pour apprendre a parler en François et en Anglois (Rouen, 1563), and the Coloquios familiares moy convenientes $y$ mas prouechosos de quantos salieron fasta agora, para qualquiera qualidad de personas desseosas de saber hablar y escribir Español y Frances (Antwerp, 1568). The most popular work by Meurier was his Thresor des Sentences dorees, Dicts, Proverbes, Refrains et Dictions communs, reduicts selon l'ordre alphabeticq en quatre langues: à çavoir, Latin, Espagnol, Thiois et François, of which the printers Nicolas Lescuyer of Rouen and Jean d'Ogerolles of Lyon produced respective editions in 1577. Gabriel Meurier, who taught Spanish, Italian, French, accounting and arithmetic, published in total around twenty works about teaching that achieved great success, for it is estimated that the booksellers Plantin and J. Van Waesberghe alone sold one thousand copies of his works between 1558 and $1587 .{ }^{8}$

Even if from the first decades of the sixteenth century large numbers of polyglot works were published in the Low Countries for the learning of various vernacular tongues, it would take a few decades for the bulk of the grammars and manuals for the teaching of foreign tongues exclusively addressing the specific needs of a given linguistic community of speakers to be published elsewhere in Europe. A survey of a sample of books for foreign language instruction in other parts of Europe (namely, Spain, France, and Italy) will prove highly illuminating in terms of cultural trends and international political relations of the time. For example, in the sixteenth century, Spanish became the most popular language among the Italian high society, and hence there soon appeared the

\footnotetext{
${ }^{8}$ For more on Gabriel Meurier, see Bourland (1938).
} 
first Spanish grammar for Italians: Giovanni Mario Alessandri d'Urbino's Il paragone della lingua toscana et castigliana (Naples, 1560), written entirely in Italian. It only went to one edition due to the publication just six years later of the successful work by Giovanni Miranda Osservationi della lingua Castigliana (Venice, 1566). Indeed, Miranda's grammar, considered "one of the key, if not the key bilingual grammar in the history of the teaching of Spanish to speakers of other languages" (Breva-Claramonte 2000:720), went through ten editions in Venice in the sixteenth-century alone. As Lope Blanch points out, "since it served as a model to French, English, and German grammarians it was important well beyond Italy" (Lope Blanch 2001:96). When it comes to Spaniards wishing to learn Italian, we find the Arte muy curiosa por la qual se enseña muy de rayz, el entender, y hablar de la lengua italiana (Medina del Campo, 1596) by Francisco Trenado de Ayllón.

As mentioned above, the frequent hostilities between Spain and France determined mutual interest in their respective languages. These military and political obstacles were compounded by the fact that for sixteenth-century France and Spain, Italy was the main cultural and artistic referent, and therefore their chief source for linguistic capital. Baltasar de Sotomayor's Grammatica con reglas muy provechosas y necessarias para aprender a leer y escrivir la lengua Francesa, conferida con la Castellana (Alcalá de Henares, 1565) was the first manual for the learning of French published in Spain. Jacques Ledel's (alias Liaño) Vocabulario de los vocablos que mas comunmente se suelen usar. Puestos por orden del Abecedario, en Frances, y su declaración en Español (Alcalá de Henares, 1565), appeared as an appendix to some copies of Sotomayor's grammar. Both works were published the same year, in the same city, by the same printers. Sotomayor's book exclusively addressed his fellow countrymen, who were at the time eager to learn French after Philip II's marriage with Elizabeth of Valois in 1560. The new French queen must be held responsible for the francization of the Spanish Court of the time. It would take seventy years for the appearance in Madrid of the second edition of Grammatica Francessa (1635) by Diego de Cisneros (also known as Fray Diego de la Encarnación. ${ }^{9}$

\footnotetext{
${ }^{9}$ The first edition of this work was published in 1624 in Douai, which was at the time under the control of the Spanish Crown. Douai was of cultural, commercial and political importance from the fifteenth to the first decades of the seventeenth century.
} 
The first book for the teaching of Spanish in France was N. Charpentier's Parfaicte méthode pour entendre escrire et parler la langue espagnole (Paris, 1596), published anonymously. However, the truly influential Spanish grammar book for sixteenth-century Frenchmen was César Oudin's Grammaire et observations de la langue espagnolle, recueillies et mises en François (Paris, 1597), which underwent six editions between 1597 and 1630. Indeed, César Oudin, who worked as secretary-interpreter of Henry IV of France, is without any doubt the most important name in the teaching of Spanish in France at the end of the sixteenth and the beginning of the seventeenth centuries. ${ }^{10}$ Oudin moreover wrote Refranes y proverbios españoles traducidos en lengua francesa. Proverbes espagnols traduits en François (Paris, 1605); Tesoro de las dos lenguas francesa y española - Thresor des deux langues françoise et espagnole (Paris, ${ }^{1606)}{ }^{11}$ and the small manual of conversation Diálogos muy apacibles escritos en lengua española y traducidos al francés. Dialogues tres plaisants écrits en langue espagnole et traduits en français (Paris, 1608). At the beginning of the seventeenth century, we find Jean Saulnier's Introduction en la langue espagnolle par le moyen de la françoise (Paris, 1608), and, later on, his more elaborated Nouvelle grammaire italienne et espagnole declare par nostre langue françoise (Paris, 1635).

As for grammars composed with the purpose of teaching Italian to Frenchmen, we can single out Jean-Pierre de Mesmes's Grammaire italienne composée en francoys (Paris, 1548), and the French translation

\footnotetext{
At the time, due to administrative, military and religious needs and interests, the city gathered an important number of Spaniards, who felt the need to learn French to carry out their jobs and to communicate with the locals. Therefore, Fray Diego de la Encarnación, who then lived in a convent in the city and taught Divinity in its University, did have in mind the linguistic needs of his fellow countrymen when devising his work.

${ }^{10}$ In February 1597 Henry IV of France appointed César Oudin Secretary-Interpreter of the King, a position he held until Louis XIII, successor of Henry IV to the throne of France, granted it to Oudin's competitor Ambrosio de Salazar. César Oudin's works outlived him by many years, partly thanks to his eldest son, Antoine Oudin, who inherited the position of interpreter at Court, and who repeatedly published and corrected his father's works after his death. Antoine also published his own titles: Grammaire Française (1633), Recherches italiennes et françaises and Curiosités françaises (1640), and the Dictionnaire Italien et Français (1681).

${ }^{11}$ In 1609 another Tesoro appeared in Geneva, this time including Italian as well. Its author was the Bolognese Girolamo Vittori. César Oudin's work was entirely copied in the French and Spanish parts without acknowledging the source.
} 
of Alberto Accarigi da Cento's La Grammatica volgare di M. A. de gl' Acharsi da Cento (Venice, 1537) as La grammaire de M. Albert de la Charisi da Cento, tournee de tuscan en francois (Louvain, 1555), published by Bartholomeus Gravius. In contrast to the French interest for Italian, it would take many years for the first French grammar specifically designed for Italians to appear: this was the brief and schematic Pietro Durante's La grammatica italiana per imparare la lingua francese (Rome, 1625). Before Durante, Italians wishing to learn French could use one of the polyglot works previously mentioned, the Praecepta gallici sermonis (Strasbourg, 1607) by Philippe Garnier, or the Linguae gallicae et Italicae hortulus (Halle, 1608) by Abraham de La Faye. Durante's grammar was followed by Antoine Fabre's Grammatica italiana per imparare la lingua italiana, francese et espanola (Rome, 1626), and Giovanni Alessandro Lonchamps's Trattato della Lingua Francese e Italiana (Rome, 1638). Indeed, handbooks for the teaching of vernaculars multiplied in the seventeenth century, particularly in the case of certain languages in some countries, such as Spanish in France and French in Italy. These seventeenth-century language handbooks addressing specific audiences were mostly printed in the countries where they were meant to be sold, thus encouraging diversification in terms of centres of publication. This, however, goes beyond the temporal scope of this article.

The bibliographical review below offers a list of the sixteenthcentury printed language manuals expressly designed to teach a single language to speakers of a particular tongue. Although in the fifteenth century some books of this sort had been published, for instance, as has been mentioned, William Caxton's French-English vocabulary, the great majority of the material of this kind was to appear from the sixteenth century onwards. The following list gathers sixteenth-century grammars, dictionaries and language handbooks with the possible linguistic combinations of Italian, French, Spanish and English, the first three being the most popular modern languages in sixteenth-century Western Europe, and hence the most representative ones offering an insight into the foreign language learning map of the time. In contrast, English was generally ignored in most Western European countries until well into the eighteenth century: in sixteenth-century France, English teachers and English manuals were few, and it was only in the seventeenth century that proper handbooks such as the Alphabet 
anglais (Rouen, 1639) and the Grammaire anglaise by the London merchant Georges Mason (Paris, 1622) began to appear; in Portugal there were no specific handbooks for the teaching of English until 1700, and in Spain, not until 1759, during the reign of King Charles III, was the study of English encouraged. ${ }^{12}$ The list below is arranged first by linguistic combination and then, in two sections: one for primary sources chronologically arranged, and another for a selection of secondary sources that focus on each linguistic combination. For a general overview of Italian, French, Spanish and English as foreign languages in the Renaissance, see instead (Jekel De Jongh 1949; Simonini 1951; Caravolas 1994; Hüllen 2001).

\section{List of works}

\section{Italian \& Spanish}

\section{Primary sources $^{13}$}

Christoforo de Escobar. Dictionarium trium linguarum [Latin, Italian and Spanish] (Venice: Augustinus de Zannis de Portesio, 1512).

Christoforo de Escobar. Vocabularium ex latino sermone in Siciliensem et hispaniensem denuo traductum (Venice: Bernardinum Benalium Bergomensem, 1520).

Alfonso de Ulloa. Introdutione del Signor Alphonso di Uglioa nella quale s'insegna pronuntiare la lingua Spagnuola (Venice: Gabriel Giolito, 1553).

Giovanni Mario Alessandri d'Urbino. Il paragone della lingua toscana et castigliana (Naples: M. Cancer, 1560).

\footnotetext{
${ }^{12}$ On the low status of English as an international language in Early Modern Europe, see Cardim (1922), Burke (2004), Maclean (2009). Early English Books Online (EEBO) (url: <http:/ / eebo.chadwyck.com/home>; last accessed 15/7/2013) has been essential in carrying out the bibliographical searches for all the works printed in England. The Lexicons of Early Modern English (LEME) database has proved very helpful as well (url: <http:/ /leme.library.utoronto.ca>; last accessed 15/7/2013).

Finally, although Welsh is not within the scope of this article, it is also worthwhile to mention that, in the island of Great Britain and for its inhabitants only, EnglishWelsh dictionaries were also published during the sixteenth century, namely, William Salesbury's A dictionary in Englyshe and Welshe moche necessary to all suche Welshemen as wil spedly learne the englyshe to[n]gue (London, 1547).
}

${ }^{13}$ References to first editions only. 
Giovanni Miranda. Osservationi della lingua Castigliana (Venice: Giolitti, 1565).

Orazio Toscanella. Dittionario volgare et latino (Venice: Comin da Trino da Monferrato, 1568).

Christobal de las Casas. Vocabulario de las dos Lenguas Toscana y Castellana, con una introducción para la correcta pronunciación de ambas lenguas (Seville: Francisco Aguilar, 1570; Venice: Damian Zenaro, 1576).

Francisco Trenado de Ayllón. Arte muy curiosa por la qual se enseña muy de rayz, el entender, y hablar de la lengua italiana (Medina del Campo: Sanctiago del Canto, 1596).

\section{Secondary sources}

$\diamond$ On the teaching of Spanish as a foreign language in Renaissance Europe

Aquilino Sánchez Pérez. Historia de la enseñanza del español como lengua extranjera (Madrid: Sociedad General Española de Librería, 1992).

Manuel Breva-Claramonte. "The teaching of Spanish in 16th-century Europe." Eds . Sylvain Auroux, E. F. K. Koerner, Hans-Josef Niederehe, and Kees Versteegh. History of the Language Sciences: An International Handbook on the Evolution of the Study of Language from the Beginnings to the Present (Berlin-New York: Walter de Gruyter, 2000: 717-723).

$\diamond$ On the teaching of Italian in Spain and of Spanish in Italy

Anna Maria Gallina. Contributi alla storia della lessicografia italo-spagnola dei secoli XVI e XVII (Firenze: L. S. Olschki, 1959)

Juan M. Lope Blanch. "Las Osservationi de Giovanni Miranda (Venecia, 1566)." Eds. E. F. K. Koerner and Hans-Josef Niederehe. History of linguistics in Spain/Historia de la linguistica en Espana (Amsterdam: Benjamins, 2001: 96-106).

$\diamond$ On the teaching of Spanish in the sixteenth-century

Antonio Roldán. "Motivaciones para el estudio del español en las gramáticas del siglo XVI." Revista de Filología Española 58 (1976): 201-229.

\section{Italian \& French}

\section{Primary sources}

Francesco Alunno Del Bailo. Le ricchezze della lingua volgare (Venice: Aldo Manuzio, 1543). 
(8) ederi 23 (2013)

Jean-Pierre de Mesmes. Grammaire italienne, composée en Françoys (Paris: Estienne Groulleau or Gilles Corrozet, 1548).

La grammatical volgare di M. Alberto de gl'Acharisi Dacento [...] tournée de Tuscan en François (Leuven: Bartholomeus Gravius, 1555).

Pannonius. Petit vocabulaire en langue françoise et italienne (Lyon: Roger de Brey, 1578).

Giovanni Antonio Fenice. Dictionnaire françois et italian (Morges: Jean Le Preux for the Parisian editors Jacques Du Puys and Nicolas Nivelle, 1584; Geneva, Pierre Canal, 1598).

\section{Secondary sources}

$\diamond$ On the teaching of French as a foreign tongue in Renaissance Europe

Jan De Clercq, Nico Lioce, and Pierre Swiggers, eds. Grammaire et enseignement du francais, 1500-1700 (Leuven: Peeters, 2000).

$\diamond$ On the teaching of French in Italy

Nadia Minerva and Carla Pellandra. Insegnare il francese in Italia: repertorio analitico di manuali pubblicati dal 1625 al 1860 (Bologna: CLUEB, 1997).

$\diamond$ On the teaching of Italian in Renaissance Europe

Claudio Marazzini. "The teaching of Italian in 15th- and 16th-century Europe." Eds. Sylvain Auroux, E. F. K. Koerner, Hans-Josef Niederehe, and Kees Versteegh. History of the Language Sciences: An International Handbook on the Evolution of the Study of Language from the Beginnings to the Present (Berlin-New York: Walter de Gruyter, 2000: 699-705).

$\diamond$ Particularly for the teaching of Italian in France

Nicole Bingen. "Sources et filiations de la 'Grammaire Italienne' de JeanPierre de Mesmes." Bibliothèque d'Humanisme et Renaissance 3/46 (1984): 633-638.

Nicole Bingen. Le Maître italien (1510-1660): bibliographie des ouvrages d'enseignement de la langue italienne destines au public de langue francaise, suivie d'un repertoire des ouvrages bilingues imprimes dans les pays de langue francaise (Brussels: $\mathrm{E}$. Van Balberghe, 1987).

Emile Picot. Les italiens en France au XVIe siecle (Rome: Vecchiarelli editore, 1995). 


\section{Spanish \& French}

\section{Primary sources}

Baltasar de Sotomayor. Grammatica con reglas muy provechosas y necessarias para aprender a leer y escrivir la lengua Francesa, conferida con la Castellana (Alcalá de Henares: Pedro de Robles y Francisco de Cormellas, 1565).

Jacques Ledel (alias Liaño). Vocabulario de los vocablos que mas comunmente se suelen usar. Puestos por orden del Abecedario, en Frances, y su declaración en Español (Alcalá de Henares: Pedro de Robles \& Francisco de Cornellas, 1565). This work was published as an appendix to some copies of Sotomayor's grammar.

Gabriel Meurier. Coniugaciones, Arte y Reglas muy propias y necessarias para los que quisieren deprender Español y Frances (Antwerp: Jan van Waesberghe, 1568).

Gabriel Meurier. Coloquios familiares moy convenientes y mas prouechosos de quantos salieron fasta agora, para qualquiera qualidad de personas desseosas de saber hablar y escribir Español y Frances (Antwerp: Jan van Waesberghe, 1568).

N. Charpentier (published anonymously). Parfaicte méthode poor entendre escrire et parler la langue espagnole (Paris: Matthieu Guillemot, 1596).

César Oudin. Grammaire et observations de la langue espagnolle, recueillies et mises en François (Paris: Marc Orry, 1597).

Henricus Hornkens. Recueil de dictionaires Francoys, Espaignolz et Latins. Recopilacion de Dictionarios Franceses, Españoles y Latinos (Brussels: Rutger Velpius, 1599).

\section{Secondary sources}

\section{On the teaching of French in Spain}

Hans-Josef Niederehe. "Les dictionnaires franco-espagnols jusqu'en 180o." Histoire Épistémologie Langage 9/ 2 (1987): 13-26.

J. Fidel Corcuera Manso and Antonio Gaspar Galan. La lengua francesa en Espana en el siglo XVI: estudio y edicion del Vocabulario de los vocablos de Jacques de Liano, Alcala de Henares, 1565 (Zaragoza: Prensas Universitarias de Zaragoza, 1999).

Brigitte Lépinette. El francés y el español en contraste y en contacto, siglos XVXVII: estudios de historiografia lingüística: lexicografia, gramática, traducción (Valencia: Universitat de València, 2001). 
Denise Fischer, Juan F. García Bascunana, and María Trinidad Gómez. Repertorio de gramáticas y manuales para la enseñanza del francés en España (1565-1940) (Barcelona: PPU, 2004).

Gonzalo Suárez Gómez. La enseñanza del francés en España hasta 1850: ¿Con qué libros aprendían francés los españoles? (Barcelona: PPU, 2008).

$\diamond$ On the teaching of Spanish in Renaissance France

Brigitte Lepinette. "La Lexicographie franco-espagnole avant le Tesoro de las dos lenguas de Cesar Oudin (1606)." Travaux de Linguistique et de Philologie 28 (1990): 317-342.

Sabina Collet Sedola. "Gramáticos y gramáticas: España en Francia (16001650)." Ignacio Arellano, et al. eds., Studia aurea: Actas del III Congreso de la AISO, Toulouse, 1993 (Pamplona: GRISO; Toulouse: LEMSO, 1996, 161-168).

\section{English \& French}

\section{Primary sources}

Alexander Barclay. Here begynneth the introductory to wryte, and to pronounce frenche compyled by Alexander Barcley (London: Robert Coplande, 1521).

Pierre Valence. Introductions in Frensshe (London: W. de Worde, 1528?).

John Palsgrave. Lesclarcissement de la langue francoyse (London: Richard Pynson, ca. 1524, finished by Johan Haukyns, 1530).

Giles Duwes (or Du Wés). An introductorie for to lerne to rede, to pronounce, and to speake Frenche (London: Thomas Godfray, 1533?).

Pierre Du Ploiche. A treatise in English and Frenche right necessary and proffitable for al young children (London: Rychard Grafton, 1551).

Gabriel Meurier. Traité pour apprendre a parler en François et en Anglois (Rouen: Bonav. Belis, 1563).

Claudius Hollyband. The French Littelton A most easie, perfect and absolute vvay to learne the frenche tongue (London: Thomas Vautroullier, 1566).

L[ucas?]. H[arrison?]. A Dictionarie French and English (London: Henry Bynneman, 1571).

John Rastell. The expositions of the termes of the lawes of Englande with diuers propre rules and principles of the lawe, aswell oute of the bookes of master Litleton, as of other. Gathered both in Frenche and English (London: Richardi Tottel, 1572). 
Claudius Hollyband (Claude De Sainliens or Desainliens). The French schoolemaister wherin is most plainlie shewed, the true and most perfect way of pronouncinge of the French tongue, without any helpe of maister or teacher (London: William How for Abraham Veale, 1573).

John Baret. An aluearie or triple dictionarie in Englishe, Latin, and French: very profitable for all such as be desirous of any of those three languages (London: Henry Denham, 1574).

G. Ledoyen de la Pichonnaye. A playne treatise to learne in a short space the Frenche tongue deuided in twoo bookes (London: Henry Denham, 1576).

John Baret. An aluearie or quadruple dictionarie containing foure sundrie tongues: namelie, English, Latine, Greeke, and French (London: Henry Denham, 1580).

Jacques Bellot. The Englishe Scholemaister. Conteyning many profitable preceptes for the naturall borne french men, and other straungers that haue their French tongue, to attayne the true pronouncing of the Englishe tongue (London: Thomas Purfoote, 1580).

Claudius Hollyband. De pronuntiatione linguae Gallicae libri duo (London, Thomas Vautrollerius, 1580).

Claudius Hollyband. The treasurie of the French tong teaching the waye to varie all sortes of verbes (London: Henrie Bynneman, 1580).

Claudius Hollyband. A treatise for declining of verbes, which may be called the second chiefest worke of the french tongue (London: Thomas Vautrollier, 1580).

Jacques Bellot. The French methode wherein is contained a perfite order of grammer for the French tongue. Made and set forth by Iames Bellot, gentleman of Caen in Normandy (London: Robert Robinson, 1588).

De la Mothe. The French alphabet (London: Richard Field, 1592).

John Eliot. Ortho-epia Gallica. Eliots fruits for the French (London: Richard Field for John Wolfe, 1593).

Claudius Hollyband. A dictionarie French and English published for the benefite of the studious in that language (London: Thomas Orwin, 1593).

\section{Secondary sources}

\section{$\diamond$ On the teaching of French in Medieval England}

Jean Gessler. La maniere de langage qui enseigne a bien parler et ecrire le francais: modeles de conversations composes en Angleterre a la fin du XIVe siecle (Bruxelles: Paris: L'Edition universelle, E. Droz, 1934: 23-29). 
W. Rothwell. "The Teaching of French in Medieval England." The Modern Language Review 1/63 (1968):37-46.

$\diamond$ On the teaching of French in early modern England

Kathleen Rebillon Lambley. The teaching and cultivation of the French language in England during Tudor and Stuart times (Manchester, 1920).

Douglas A. Kibbee. For to Speke Frenche Trewely: The French Language in England, 1000-1600: Its Status, Description and Instruction (Amsterdam/Philadelphia: John Benjamins, 1991).

Gabriele Stein. John Palsgrave as Renaissance Linguist: A Pioneer in Vernacular Language Description (Oxford: Clarendon Press, 1997).

\section{English \& Italian}

\section{Primary sources}

William Thomas. Principal rules of the Italian grammer with a dictionarie for the better vnderstandyng of Boccace, Petrarcha, and Dante (London: Thomas Berthelet, 1550).

David Rowland, translator. A comfortable ayde for Schollers, full of variety of sentences, gathered out of an Italian author, (intituled in that tongue, Specchio de la lingua Latina) (London: H. Wykes, 1568).

Henry Granthan, translator. An Italian grammer written in Latin by Scipio Lentulo a Neapolitane: and turned into Englishe by Henry Granthan (London: Thomas Vautrollier, 1575).

John Florio. Florio his firste fruites which yeelde familiar speech, merie prouerbes, wittie sentences, and golden sayings. Also a perfect induction to the Italian, and English tongues (London: Thomas Dawson, 1578).

Claudius Hollyband. Campo di fior or else The flourie field of foure languages of M. Claudius Desainliens, aliâs Holiband: for the furtherance of the learners of the Latine, French, English, but chieflie of the Italian tongue (London: Thomas Vautrollier, 1583).

John Florio. Florios second frutes to be gathered of twelue trees, of diuers but delightsome tastes to the tongues of Italians and Englishmen. To which is annexed his Gardine of recreation yeelding six thousand Italian prouerbs (London: T. Orwin, 1591).

Claudius Hollyband. The Italian Schoole-maister: contayning rules for the perfect pronouncing of th'italian tongue (London: Thomas Purfoot, 1597). 
John Florio. A vvorlde of wordes, or Most copious, and exact dictionarie in Italian and English, collected by Iohn Florio (London: Arnold Hatfield, 1598).

\section{Secondary sources}

$\diamond$ On the teaching of Italian in England

Rinaldo C. Simonini, Jr. "Italian-English Language Books of the Renaissance." Romanic Review 4/ 42 (1951): 241-244.

Rinaldo C. Simonini, Jr. "The Italian Pedagogy of Claudius Hollyband." Studies in Philology 49 (1952): 144-154.

Clifford Chalmers Huffman. Elizabethan impressions: John Wolfe and his press (New York: AMS Press, 1988).

Warren Boutcher. "'A French Dexterity, \& an Italian Confidence': New Documents on John Florio, Learned Strangers and Protestant Humanist Study of Modern Languages in Renaissance England from c. 1547 to c. 1625." Reformation 2 (1997): 39-109.

Jason Lawrence. "Who the devil taught thee so much Italian?": Italian language learning and literary imitation in early modern England (Manchester: Manchester University Press, 2005).

\section{English \& Spanish}

\section{Primary sources}

Anonymous. The boke of Englysshe, and Spanysshe and A very profitable boke to lerne the maner of redyng, writing, E speaking English $\mathcal{E}$ Spanish (London: Robert Wyer, 1554?).

Antonio del Corro. Reglas gramaticales para aprender la lengua espanola y francesa (Oxford: Joseph Barnes, 1586)

John Thorius, translator. The Spanish grammer voith certeine rules teaching both the Spanish and French tongues (London: John Wolfe, 1590).

Richard Percyvall. Bibliotheca Hispanica Containing a grammar; with a dictionarie in Spanish, English, and Latine (London: John Jackson, 1591).

William Stepney. The Spanish schoole-maister (London: Richard Field, 1591).

Richard Percyvall and John Minsheu. A dictionarie in Spanish and English (London: Edm. Bollifant, 1599).

Richard Percyvall and John Minsheu. A Spanish gramar (London: Edm. Bollifant, 1599). 


\section{Secondary sources}

Sofía Martín-Gamero. La enseñanza del inglés en España: desde la Edad Media al siglo XIX (Madrid: Gredos, 1961).

Roger J. Steiner. Two Centuries of Spanish and English Bilingual Lexicography (1590-1800) (The Hague-Paris: Mouton, 1970).

Patricia Shaw. "Noticias y conocimientos acerca de la lengua española en la Inglaterra del siglo XVII." Estudios ofrecidos a Emilio Alarcos Llorach con motivo de sus XXV años de docencia en la Universidad de Oviedo, Vol. 4 (Oviedo: Servicio de Publicaciones Universidad de Oviedo, 1976-1983: 325-348).

Heberto H. Hernández Urdaneta. Dictionaries in Spanish and English from 1554 to 1740: Their Structure and Development (Soria: Diputación de Soria, 2010).

\section{References}

Bischoff, Bernhard 1961. "The Study of Foreign Languages in the Middle Ages." Speculum 2/36: 209-224.

Bourland, Caroline B. 1933. "The Spanish Schoole-Master and the Polyglot Derivatives of Noël de Berlaimont's Vocabulare." Revue Hispanique: Recueil Consacré á l'Étude des Langues, des Littératures et de l'Histoire des Pays Castillans, Catalans et Portugais 1/81: 283-318.

Bourland, Caroline B. 1938. "Algo sobre Gabriel Meurier: Maestro de Español de Amberes (1521-1597?)." Hispanic Reviezv 2/6: 139-152.

Brefeld, Josephine 1994. A Guidebook for the Jerusalem Pilgrimage in the Late Middle Ages. Hilversum: Verloren.

Burke, Peter 2004. Languages and Communities in Early Modern Europe. Cambridge: Cambridge University Press.

Caravolas, Jean-Antoine 1994. La didactique des langues. Precis d'histoire I: 1450-1700. Montreal: Presses de L'Universite de Montreal \& Tübingen: G. Narr.

Cardim, Luis 1922. Some Notes on the Portuguese-English and EnglishPortuguese Grammars to 1830. Porto: Tipografia de "A Tribuna."

Fontainas, Jean Peeters 1965. Bibliographie des impressions espagnoles des PaysBas méridionaux. Nieuwkoop: B. de Graaf.

Hüllen, Werner 2001. "Reflections on Language in the Renaissance." Eds. Martin Haspelmath et al. Language Typology and Language Universals. An International Handbook. Berlin: Walter de Gruyter: 210-222. 
Jekel De Jongh, William Frederick 1949. Western Language Manuals of the Renaissance. Albuquerque: University of New Mexico Press.

Kibbee, Douglas A. 200o. "Language Instruction for Western European Travelers." Eds. John Block Friedman et al. Trade, Travel, and Exploration in the Middle Ages: An Encyclopedia. New York-London: Garland: 330-331.

Labarre, Albert 1975. Bibliographie du Dictionnaire d'Ambrogio Calepino 15021779. Baden-Baden: Valentin Koerner.

Maclean, Ian 2009. "English Books on the Continent, 1570-1630." Learning and the Market Place: Essays in the History of the Early Modern Book. LeidenBoston: Brill: 339-370.

Penzl, Herbert 1984. "'Gimer min ros': How German Was Taught in the Ninth and Eleventh Centuries." The German Quarterly 3/57: 392-401.

Roldán Pérez, Antonio and José Miguel Hernández Terrés 2002. "Labor editora de Bartolomé Gravio." Eds. Miguel Ángel Esparza Torres et al. Actas del III Congreso Internacional de la Sociedad Española de Historiografia Lingüística. Hamburg: Helmut Buske Verlag: 415-430.

Simonini Jr., R. C. 1951. "The Genesis of Modern Foreign Language Teaching." The Modern Language Journal 3/35: 179-186.

Stein, Gabriele 1988. "The Emerging Role of English in the Dictionaries of Renaissance Europe." Folia Linguiistica Historica 9: 29-138.

Suárez Gómez, Gonzalo 2008. La enseñanza del francés en España hasta 1850: ¿Con qué libros aprendían francés los españoles? Barcelona: PPU.

How to cite this note:

Sumillera, Rocío G. "Sixteenth-Century Italian, French, Spanish and English Language Learning Material. A Bibliographical Study." SEDERI 23 (2013): 139158.

Author's contact: sumillera@ugr.es

Submission: 26/o9/2012 - Acceptance: 08/01/2013 